\title{
The use of ultrasonics in phenotype testing of rams
}

\author{
Tapani Hellman, Matti Ojala and Mikko Varo \\ Department of Animal Breeding, University of Helsinki, 00710 Helsinki 7
}

\begin{abstract}
An experiment in developing phenotype testing of rams was begun in 1975 . One of the investigated characteristics was the area of the MLD measured ultrasonically. The experiment consisted of 130 rams on two feeding levels. In one group the rams were fed both hay and concentrates ad libitum, while in the other group concentrates were restricted. 124 of the rams were ultrasonically photographed, 61 from the ad libitum and 63 from the restricted feeding group. Weights (5 mths), daily gains and areas of

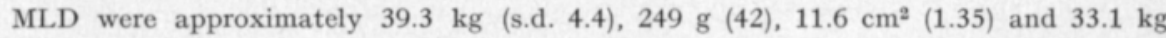
(4.6), $182 \mathrm{~g} \mathrm{(32)}$ and $9.4 \mathrm{~cm}^{2}(0.96)$ respectively. The ultrasonic area of the MLD correlated 0.52 and 0.32 with the area measured from carcass. As a rule the ultrasonic area of the MLD correlated positively with other measures of live animals and slaughter results, but correlations with measures of relative meatiness were almost all nonsignificant. In completing the information concerning dressing weight and quantity of meat given by live weight, the ultrasonic area of the MLD proved to be the best of the measures on live animals. The rams in this experiment came from all over Finland but the next stage will consist mostly of progeny of the rams now selected (the two best and the two medium ones from both groups). With progeny testing the success of selection based on phenotype will be checked.
\end{abstract}

\section{Introduction}

The chief income in sheep farming comes today from mutton. For this reason breeding work has concentrated on improving mutton characters. Finnsheep are not traditionally a good breed for mutton purposes but a good deal of heritable variation has been found in characters important for mutton production (VARO 1968). The selection must be based on traits one can measure on live animals so that the best mutton animals can be secured for breeding. The best measure for the meat quantity is live weight. In estimating the fullness of meat on live animals attempts have been made to complete the information obtained from live weight with different body measurements. However, it is not possible to distinguish, for example, the effect of surface fat on body measures.

The area of the eye-muscle (Musculus longissimus dorsi, MLD) is a commonly used measure for fullness of meat in evaluation based on slaughter results. In Norway sheep breeders have developed different indices and the ram index includes, among others, the area of MLD measured in carcasses of 10 ram progeny (EIKJE 1972). The genetic gain in the area of MLD has 
been estimated at $1.8 \%$ /year based on the index above (EIKJE 1975). In Norway attempts have also been made to estimate the area of the MLD indirectly with different measures from live animals to avoid the cutting of carcasses (VÅBENo 1973) but the results have not been satisfactory. Likewise in Finland it has been confirmed that the area of the MLD gives significant extra information of the amount and fullness of meat in young rams compared with the estimate based only on live weight (VARo and Hellman 1976).

The ultrasonic technique has made it possible to measure the area of the MLD on live animals. For instance in Denmark preliminary ultrasonic measurements of MLD in sheep have been made (ANON 1975) and the results have been so promising that the research is being continued. When experiments for developing phenotype testing of rams were begun in Finland it was decided to study the use of ultrasonics as an aid in testing.

\section{Material}

The phenotype testing experiment of rams arranged at the Pirtti farm in 1975 was the first part of a joint research project planned for three years. The participants in the research are the Institutes of Animal Breeding and Animal Husbandry in the Agricultural Research Centre, the Sheep Breeders' Association and the Department of Animal Breeding in the University of Helsinki. In the first part of the experiment individual differences in growth rate were mainly examined, while the second part will also contain comparisons between progeny groups sired by the rams selected in the first part. The rams in the experiment were purchased from recorded flocks throughout Finland. Altogether there were 130 ram lambs in the experiment. The rams were fed on two levels and the feeding groups will be called hereafter the restricted and the ad libitum group. The rams in the restricted group were fed hay ad libitum while concentrates were restricted, the rams in the ad libitum group were fed both hay and concentrates ad libitum. Statistically the feeding groups have been analysed separately.

The age of the rams varied from 70 to 90 days at the start and they were fed until five months of age. The means, standard deviations and variation coefficients of weights and daily gains during the experiment as well as some other basic data are presented in Table 1.

The eye-muscles of 124 rams were ultrasonically photographed with Scanogram 721 equipment. 63 of the rams came from the restricted and 61 from the ad lib. group. The photos were taken from the left side of the animals behind the last rib or on the first lumbar vertebra. Several photos from the same place were taken and the two best ones were selected for measuring. As a practical point in scanning sheep may be mentioned that the automatic oiling system of the machine was not sufficient and the measuring point was oiled by hand before scanning. After being drawn on transprent paper the area of the MLD $\left(\mathrm{cm}^{2}\right)$ was measured with a planimeter and the depth of the MLD $(\mathrm{mm})$ was taken two centimetres from the midline. The existence of possible surface fat was also estimated. The two photos in Figure 1 are presented as examples from both feeding groups. The scale in the photos is 1: 2.35. 
Table 1. Means, standard deviations and coefficients of variation of weights, daily gains and some other basic data.

\begin{tabular}{|c|c|c|c|c|c|c|c|}
\hline \multirow[t]{2}{*}{ Trait } & \multicolumn{3}{|c|}{$\begin{array}{l}\text { Restricted group } \\
\mathrm{n}=63\end{array}$} & \multicolumn{3}{|c|}{$\begin{array}{l}\text { Ad libitum group } \\
\qquad \mathrm{n}=61\end{array}$} & \multirow{2}{*}{$\begin{array}{l}\text { F-test } \\
\text { between } \\
\text { groups }\end{array}$} \\
\hline & $\overline{\mathbf{x}}$ & s.d. & C.V. & $\overline{\mathbf{x}}$ & s.d. & C.V. & \\
\hline Litter size at birth $\ldots \ldots \ldots \ldots \ldots . . . .$. & 3.19 & 0.62 & 19.4 & 3.20 & 0.57 & 17.9 & - \\
\hline Survived in litter .................. & 3.02 & 0.66 & 22.0 & 3.00 & 0.55 & 18.2 & - \\
\hline Age in the beginning, days ..... & 79.5 & 8.9 & 11.2 & 78.2 & 9.1 & 11.6 & - \\
\hline Age in the end, days $\ldots \ldots \ldots \ldots \ldots 1$ & 154.0 & 0.46 & & 154.1 & 0.54 & & - \\
\hline Days in trial ........................ & 74.5 & 8.7 & 11.7 & 75.9 & 9.0 & 11.8 & - \\
\hline Weight in the beginning, $\mathrm{kg} \ldots$ & 19.5 & 4.2 & 21.5 & 20.4 & 5.1 & 25.0 & - \\
\hline Weight in the end, $\mathrm{kg}$............ & 33.1 & 4.6 & 13.9 & 39.3 & 4.4 & 11.2 & $* * *$ \\
\hline Daily gain, $g$.................... 1 & & 32 & 17.6 & 249 & 42 & 16.9 & $* * *$ \\
\hline
\end{tabular}

Significance: - nonsignificant $* * * \mathrm{p}<0.001$

Fig. 1. Ultrasonically photographed muscles of rams. Below: ad libitum feeding, area of MLD $13.8 \mathrm{~cm}^{2}$, depth of MLD $31 \mathrm{~mm}$, surface fat clearly visible. Above: restricted feeding, area of MLD $9.6 \mathrm{~cm}^{2}$, depth of MLD 23 $\mathrm{mm}$, no surface fat.
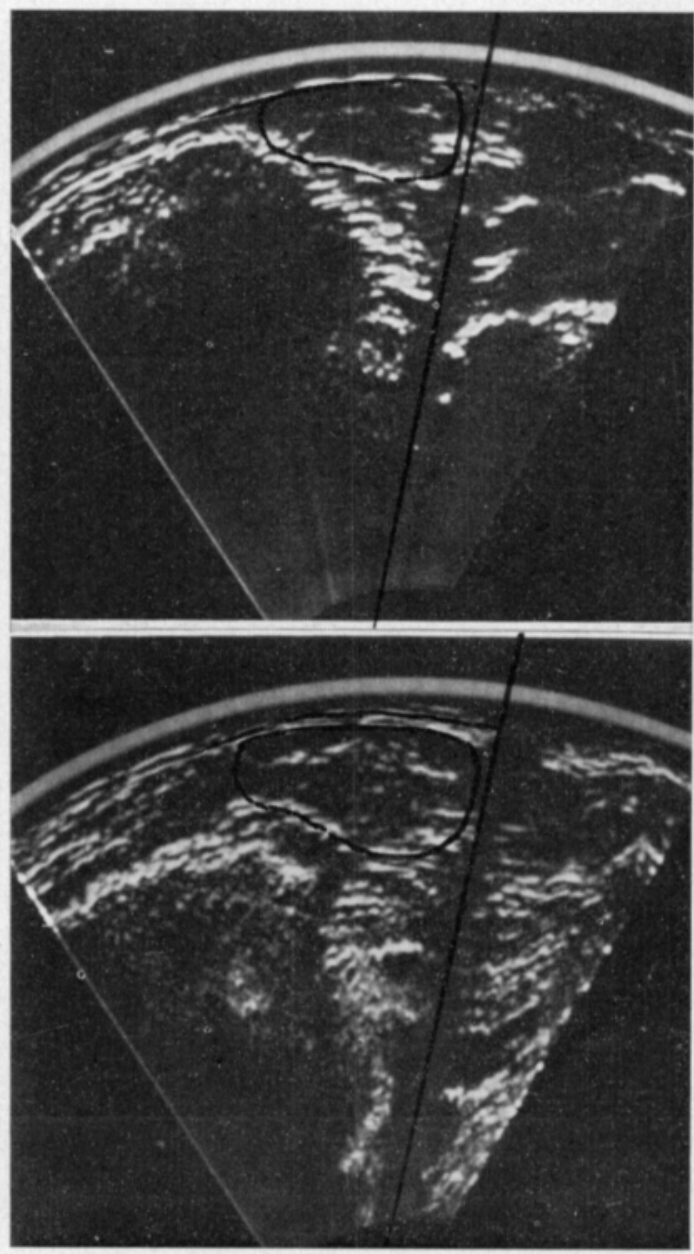
The rams averaged 163 days (s.d. 9 days) at scanning. After evaluation, 55 rams of the restricted and $\mathbf{5 1}$ of the ad libitum group were slaughtered at Karjaportti slaughterhouse at an average age of 175 days. The left halves of the carcasses were cut on the first lumbar vertebra and the MLD was drawn on transparent paper from both cutting surfaces. The leg and shoulder parts from the left half carcasses were separated into meat, bone and fat and the fillets were weighed.

The figures drawn from the two ultrasonic photos per animal are almost alike $(r=0.93)$ and the mean of the two will be used in later analyses. The mean of the two MLD areas measured from the carcasses will likewise be used because the hind surface is regularly a little smaller.

There are no great systematic errors in the material because the feeding groups will be analysed separately. However, there is considerable variation in the scanning and slaughter ages because all the animals were scanned and slaughtered at the same time. For this reason the ultrasonic and body measures were corrected to the average age of 163 days and the slaughter results respectively to 175 days.

\section{The measures of MLD on average}

The means and standard deviations of the MLD measures on live animals and carcasses are presented in Table 2 for both feeding groups. All the measures are significantly higher $(\mathrm{p}<0.001)$ in the ad lib. group. Determining the MLD area from ultrasonic photos is rather schematic, but relatively the areas are comparable when the same person interprets all the photos on the same principles.

Table 2. Ultrasonic and carcass measures of MLD.

\begin{tabular}{|c|c|c|c|c|}
\hline & \multicolumn{3}{|c|}{ ultrasonic } & \multirow{2}{*}{$\begin{array}{c}\text { carcass } \\
\text { area } \\
\mathrm{cm}^{2}\end{array}$} \\
\hline & $\begin{array}{l}\text { area } \\
\mathrm{cm}^{2}\end{array}$ & $\begin{array}{c}\text { depth } \\
\text { mm }\end{array}$ & $\begin{array}{r}\text { surface } \\
\left.\text { fat }^{1}\right)\end{array}$ & \\
\hline \multicolumn{5}{|l|}{ Restricted group $(\mathrm{n}=63)^{2}$} \\
\hline min. ........................ & 7.4 & 19.8 & 0.0 & 5.4 \\
\hline 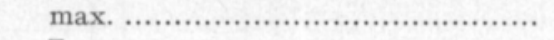 & 11.8 & 27.9 & $\left.1.1^{3}\right)$ & 13.1 \\
\hline 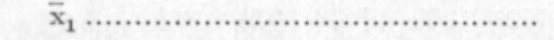 & 9.4 & 23.5 & 0.41 & 9.2 \\
\hline 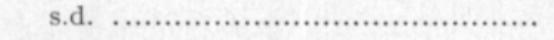 & 0.96 & 1.80 & 0.49 & 1.57 \\
\hline 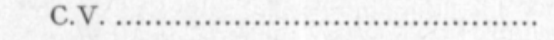 & 10.2 & 7.9 & 118.1 & 17.0 \\
\hline \multicolumn{5}{|l|}{ Ad libitum group $(n=61)^{2}$} \\
\hline 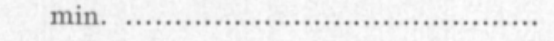 & 9.2 & 23.2 & 0.0 & 8.2 \\
\hline max. ..................................... & 18.0 & 36.5 & $\left.1.1^{3}\right)$ & 16.1 \\
\hline $\bar{x}_{2} \ldots \cdots \cdots \cdots \cdots \cdots \cdots \cdots \cdots \cdots \cdots \cdots \cdots \cdots \cdots \cdots \cdots \cdots \cdots \cdots \cdots \cdots \cdots \cdots \cdots \cdots \cdots \cdots \cdots \cdots$ & 11.6 & 26.6 & 0.93 & 11.7 \\
\hline 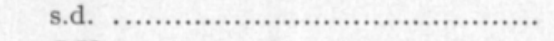 & 1.35 & 2.05 & 0.25 & 1.82 \\
\hline 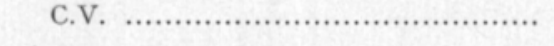 & 11.6 & 7.7 & 26.4 & 15.5 \\
\hline \multicolumn{5}{|l|}{ Differences between groups: } \\
\hline 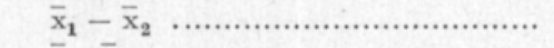 & -2.2 & -3.1 & -0.52 & -2.5 \\
\hline 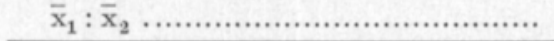 & 0.81 & 0.88 & 0.44 & 0.79 \\
\hline
\end{tabular}

1) Coding $=0$ no surface fat, 1 visible surface fat.

$\left.{ }^{2}\right)$ Number of slaughtered rams is 55 in restricted and 51 in ad libitum group.

3) Deviation from 1 is caused by correction to same age. 
The areas measured from the carcasses may be closer to the real areas of the MLD, but it should be kept in mind that the shape and size of the muscle changes for several reasons after slaughter. The schematicism in determining the areas of the MLD from the ultrasonic photos is reflected in the standard deviation which is about $10-12 \%$ of the mean, while it is $16-17 \%$ in the area measured from the carcasses. Compared with the standard deviation of the live weight at five months of age $(11-14 \%$ of the mean) the ultrasonic photos show the size differences of the rams almost as clearly. The depth of the MLD clearly varies less than the area. The surface fat determined from the ultrasonic photos reflects quite clearly the fatness of the rams, but especially in the ad lib. group the method used seems insufficient. If one wants to pay attention to the grade of fatness in selecting rams it is possible to measure the surface fat more accurately.

\section{Correlation analyses}

From the correlations between the ultrasonic measures one can note that there is an evident correlation between the depth and the area while the surface fat has correlated with neither of these (Table 3 ).

Table 3. Correlations of ultrasonic measures with each other and with other measures on live animals.

\begin{tabular}{|c|c|c|c|c|c|c|}
\hline \multirow[t]{2}{*}{ Trait } & \multicolumn{3}{|c|}{$\begin{array}{l}\text { Restricted group } \\
\mathrm{n}=63\end{array}$} & \multicolumn{3}{|c|}{$\begin{array}{l}\text { Ad libitum group } \\
\qquad \mathrm{n}=61\end{array}$} \\
\hline & 1 & 2 & 3 & 1 & 2 & 3 \\
\hline Ultrasonic area of MLD ........... 1 & - & & & - & & \\
\hline Ultrasonic depth of MLD ........... 2 & 79 & - & & 89 & - & \\
\hline Ultrasonic surface fat $\ldots \ldots \ldots \ldots \ldots . \ldots 3$ & 02 & 07 & - & 25 & 12 & - \\
\hline Live weight (5 mths) $\ldots \ldots \ldots \ldots \ldots \ldots \ldots$ & 27 & 33 & 14 & 58 & 52 & 30 \\
\hline Daily gain .................................. & -07 & 09 & -01 & 29 & 23 & 31 \\
\hline Circumference of thigh $. . . \ldots \ldots \ldots . . . . . .$. & 34 & 28 & 14 & 49 & 46 & 20 \\
\hline 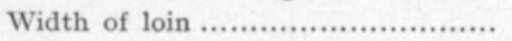 & 24 & 30 & -01 & 51 & 48 & 08 \\
\hline 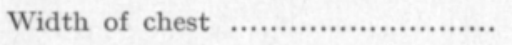 & 21 & 20 & 04 & 46 & 32 & 22 \\
\hline Heart girth .................................. & 24 & 26 & 12 & 57 & 44 & 22 \\
\hline Circumf. of front cannon $. . . \ldots \ldots \ldots . .$. & 37 & 28 & 14 & 32 & 30 & 25 \\
\hline 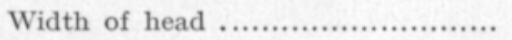 & 15 & 20 & 04 & 02 & 02 & -30 \\
\hline Length of head ........................ & 23 & 32 & 11 & 32 & 27 & 11 \\
\hline
\end{tabular}

Correlations are without zeros and decimal points.

Significance: $\left|r_{0.1} \%\right|>0.42,\left|r_{1} \%\right|>0.33,\left|r_{5} \%\right|>0.26$

The area and depth of the MLD are positively, although slightly, correlated with the live weight at five months and the body measurements. In the restricted group the ultrasonic measures have no correlation with the daily gain, likewise in the ad lib. group the daily gain correlates less than the other measures with the ultrasonic measures. In the ad lib. group the width of head has no correlation with the area and depth of the MLD. As a rule correlations are higher in the ad lib. group. 
The surface fat has no significant correlations with any trait in the restricted group but in the ad lib. group it correlates like the area and depth of the MLD although not as significantly. It is possible that the surface fat has had some effect on body measures in the ad lib. group. The negative correlation between the surface fat and the width of head differs clearly from the others. The determining of the surface fat was, however, very approximate and no certain conclusions can be drawn. On the other hand, the width of head is quite a good indication of the amount of meat in the carcass (as will be noticed later in the regression analyses). This makes the above correlation particularly interesting and worth consideration in further experiments.

From the correlations between ultrasonic measures and slaughter results (Table 4) it can be seen that in general the area and depth of the MLD correlate higher in the ad lib. group. Correlations between the surface fat and slaughter results, on the other hand, seem to be somewhat more pronounced in the restricted group. As a rule the two weeks period between the scanning and slaughter may cause some reduction in the correlations.

The correlation $0.32-0.52$ between the areas of the MLD measured ultrasonically and from carcass is not very high. It does not necessarily mean that

Table 4. Correlations of ultrasonic measures with absolute and relative slaughter results.

\begin{tabular}{|c|c|c|c|c|c|c|c|c|c|c|c|c|}
\hline \multirow{4}{*}{ Trait } & \multicolumn{6}{|c|}{ Restricted group $(\mathrm{n}=55$ ) } & \multicolumn{6}{|c|}{ Ad libitum group $(\mathrm{n}=51)$} \\
\hline & \multirow{2}{*}{\multicolumn{2}{|c|}{ area }} & \multicolumn{2}{|c|}{ MLD } & \multirow{2}{*}{\multicolumn{2}{|c|}{ surface fat }} & \multicolumn{6}{|c|}{ MLD } \\
\hline & & & & epth & & & are & & & pth & surfa & ce fat \\
\hline & & . rel. & abs. & & & & abs. & rel. & abs. & rel. & & \\
\hline Dressing weight .............. & 39 & & 38 & & 15 & & 66 & & 55 & & 25 & \\
\hline Dressing percent ............. & & 29 & & 23 & & 19 & & 45 & & 35 & & 13 \\
\hline Leg + shoulder: & & & & & & & & & & & & \\
\hline meat ....................... & 41 & 18 & 41 & 16 & 09 & -30 & 62 & -09 & 50 & -07 & 23 & -10 \\
\hline bone ....................... & & -34 & & -32 & & -12 & & -02 & & -04 & & -22 \\
\hline fat n....................... & 28 & 13 & 29 & 14 & 45 & 47 & 35 & 12 & 29 & 11 & 31 & 29 \\
\hline meat-fat ratio.......... & -03 & & 07 & & -32 & & -10 & & -09 & & -38 & \\
\hline Meat in leg + & & & & & & & & & & & & \\
\hline shoulder + fillet $\left.^{1}\right)$....... & & 10 & & 11 & & -21 & & -11 & & -07 & & -09 \\
\hline Fillet $\left.^{1}\right) \ldots \ldots \ldots \ldots \ldots \ldots \ldots \ldots \ldots \ldots \ldots \ldots \ldots$ & 39 & 10 & 41 & 13 & -02 & -20 & 43 & -04 & 46 & 10 & 08 & -12 \\
\hline 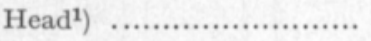 & 27 & -33 & 31 & -28 & 01 & -26 & 51 & -29 & 46 & -22 & 16 & -19 \\
\hline 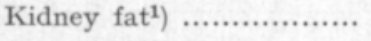 & 05 & -06 & 20 & 09 & 06 & 02 & 20 & -03 & 07 & -12 & 04 & -08 \\
\hline Area of MLD from carcass & 32 & & 30 & & 28 & & 52 & & 45 & & 21 & \\
\hline Visual points: & & & & & & & & & & & & \\
\hline fullness of meat .......... & 32 & & 28 & & 07 & & 42 & & 39 & & 17 & \\
\hline points together .......... & 32 & & 28 & & 07 & & 44 & & 40 & & 18 & \\
\hline dressing class ${ }^{2}$ ) .......... & 00 & & 00 & & 00 & & 44 & & 38 & & 06 & \\
\hline grade of fatness .......... & 18 & & 15 & & 43 & & 07 & & -10 & & 09 & \\
\hline
\end{tabular}

1) Percent of dressing weight.

2) All rams in the restricted group belong to the same class. Correlations are without zeros and decimal points.
Significance:

$\mathrm{n}=55,\left|\mathrm{r}_{0.1} \%\right|>0.43,\left|\mathrm{r}_{1} \%\right|>0.34,\left|\mathrm{r}_{5} \%\right|>0.27$

$\mathrm{n}=51,\left|\mathrm{r}_{0.1} \%\right|>0.45,\left|\mathrm{r}_{1} \%\right|>0.36,\left|\mathrm{r}_{5} \%\right|>0.28$ 
only the ultrasonic measurement would be inaccurate because the determination of the area of MLD from carcass is also open to interpretation. In general, the ultrasonically measured area (and depth) of the MLD correlates positively with the quantities of meat measured by cutting, but also the correlations with bone and fat quantities are quite clear. However, the variations in size of the rams may also influence these correlations a great deal.

The ultrasonic measures must be primarily taken as indicators of meat quantity, since of the percentual shares of meat only the percent of meat in shin $(\mathrm{r}=0.30, \mathrm{p}<0.05)$ in the restricted group and the dressing percents in both groups correlate somehow significantly with the area of the MLD. The percentual share of bone in the restricted group and the share of head of carcass in both groups have clearly correlated negatively with the area of the MLD. Although the ultrasonic measures correlate weakly with the fullness of meat found by cutting, it is surprising how clear the positive correlations are that they have with the objective evaluation points of meatiness.

The surface fat found on the ultrasonic photos correlates clearly with the absolute and percentual shares of fat in carcass and with the objective points of fatness. The accuracy in measuring the surface fat, as confirmed earlier, was not sufficient in the ad lib. group. The same can be seen now as lower correlations in the ad lib. group. The surface fat measured from the ultrasonic photos seems to reflect clearly the fatness of tissues in rams. On the other hand, no correlation was to be found with the kidney fat.

\section{Regression analyses}

The degree of certainty of the quantity and fullness of meat in rams may be estimated with measures on live animals. This has been attempted in order to determine it with a stepwise multiple regression analysis. The traits being determined were the dressing weight and percent, the absolute and percentual quantity of meat in leg plus shoulder and the meat of cuttings (leg, shoulder and fillet) in percent of the dressing weight. The determining traits were live weight (at 5 mths), daily gain, ultrasonic measures and body measures (circumference of thigh, width of loin and chest, heart girth, circumference of front cannon and width and length of head). The results of the regression analyses are presented in Table 5. It has been a restriction for a new trait to be added in the model that the significance of the increase in the coefficient of determination has been at least $0.1<\mathrm{p}<0.05$ (F-test). The significance of the total coefficient of determination of the model has been tested with analysis of variance.

The coefficient of determination for the quantity of meat is quite high while it is rather low for the fullness of meat. There is not, however, any antagonism in determining the quantity or the fullness of meat. The live weight alone gives a relatively reliable estimate of the dressing weight and quantity of meat. However, the area of the MLD gives a significant increase to the coefficient of determination and it is the second best determining trait almost in every model. Surprisingly, the width of head comes third in determining the dressing weight and quantity of meat. The next traits in determining 
Table 5. Cumulative coefficients of determination for quantity and fullness of meat calculated with traits measurable on live animals.

\begin{tabular}{|c|c|c|c|c|c|c|c|}
\hline $\begin{array}{l}\text { Sign. of } \\
\text { increase }\end{array}$ & $\begin{array}{c}\text { Restricted group } \\
\text { Trait }\end{array}$ & $\begin{array}{c}\text { INC } \\
\text { IN MCS }\end{array}$ & MCS & $\begin{array}{l}\text { Sign. of } \\
\text { increase }\end{array}$ & $\begin{array}{c}\text { Ad libitum group } \\
\text { Trait }\end{array}$ & $\begin{array}{c}\text { INC } \\
\text { IN MCS }\end{array}$ & MCs \\
\hline \multicolumn{8}{|c|}{ Dressing weight } \\
\hline$* * *$ & Live weight (5 mths) & 10.4 & 87.3 & $* * *$ & Live weight (5 mths) & 29.9 & 78.2 \\
\hline$*$ & Area of MLD & 1.5 & 88.8 & $* *$ & Area of MLD & 3.0 & 81.2 \\
\hline$*$ & Width of head & 0.6 & 89.5 & ** & Width of head & 4.3 & 84.8 \\
\hline$(*)$ & Heart girth & 0.6 & $\begin{array}{l}90.1 \\
* * *\end{array}$ & $*$ & Daily gain & 1.5 & $\begin{array}{l}86.3 \\
* * *\end{array}$ \\
\hline \multicolumn{8}{|c|}{ Dressing \% } \\
\hline$* *$ & Live weight ( 5 mths) & 23.9 & 16.5 & $* * *$ & Heart girth & 25.9 & 31.2 \\
\hline$*$ & Daily gain $(-)$ & 7.9 & $\begin{array}{l}24.4 \\
* * *\end{array}$ & $* *$ & Width of head & 8.6 & $\begin{array}{l}39.9 \\
* * *\end{array}$ \\
\hline \multicolumn{8}{|c|}{ Meat in leg + shoulder } \\
\hline$* * *$ & Live weight (5 mths) & 7.2 & 77.2 & $* * *$ & Live weight ( 5 mths) & 19.6 & 62.0 \\
\hline$* *$ & Width of loin & 2.8 & 80.4 & $*$ & Area of MLD & 3.6 & 66.0 \\
\hline$* *$ & Area of MLD & 2.8 & 83.0 & $*$ & Width of head & 5.1 & 69.9 \\
\hline$*$ & Width of chest & 1.9 & 84.7 & $*$ & Daily gain & 3.6 & 73.4 \\
\hline$(*)$ & Heart girth & 0.8 & $\begin{array}{l}85.6 \\
* * *\end{array}$ & & & & $* * *$ \\
\hline \multicolumn{8}{|c|}{ Meat $\%$ in leg + shoulder } \\
\hline$*$ & Surface fat $(-)$ & 8.9 & 9.3 & $*$ & Live weight (5 mths) $(-)$ & 9.9 & 9.9 \\
\hline$(*)$ & Width of head & 5.3 & 14.1 & & & & $*$ \\
\hline$*$ & Heart girth $(-)$ & 7.5 & 19.8 & & & & \\
\hline$(*)$ & Area of MLD & 4.7 & $\begin{array}{l}24.5 \\
* *\end{array}$ & & & & \\
\hline \multicolumn{8}{|c|}{ Meat in leg + shoulder + fillet in $\%$ of dressing weight } \\
\hline$* *$ & Width of chest $(-)$ & 19.1 & 12.9 & $* *$ & Heart girth $(-)$ & 13.7 & 13.7 \\
\hline$*$ & Width of loin & 6.8 & $\begin{array}{l}19.6 \\
* *\end{array}$ & & & & $* *$ \\
\hline
\end{tabular}

MCS $=$ multiple correlation squared $=$ coefficient of determination.

INC IN MCS = diminution in MCS, if the trait is not included.

Significance: ${ }^{* * *} \mathrm{p}<0.001,{ }^{* *} \mathrm{p}<0.01,{ }^{*} \mathrm{p}<0.05,\left(^{*}\right) 0.05 \leqq \mathrm{p} \leqq 0.1$

(-) Small value of the trait has been emphasized.

The asterisks in the MCS columns mean the significance of the total MCS.

are the daily gain, the width of chest and loin, and the heart girth, which are about equal in value.

If regression equations with three traits are formed in order to estimate the dressing weights and quantities of meat, four equations are obtained of which only one differs from the others in respect of the determining traits. The differing equation is the one for estimating the quantity of meat in the restricted group and involves the width of loin instead of the width of head. 
Ad libitum group:

Dressing weight $=-5.034+0.377 \mathrm{X}_{1}+0.391 \mathrm{X}_{2}+0.386 \mathrm{X}_{3}\left(\mathrm{R}^{2}=84.8\right)$

Quantity of meat $=-505.58+50.15 \mathrm{X}_{1}+70.06 \mathrm{X}_{2}+63.42 \mathrm{X}_{3}\left(\mathrm{R}^{2}=69.9\right)$

Restricted group:

Dressing weight $=-4.119+0.353 \mathrm{X}_{1}+0.23 \mathrm{X}_{2}+63.42 \mathrm{X}_{3}\left(\mathrm{R}^{2}=89.5\right)$

Quantity of meat $=-738.85+46.63 \mathrm{X}_{1}+73.44 \mathrm{X}_{4}+54.50 \mathrm{X}_{2}\left(\mathrm{R}^{2}=83.0\right)$

$\mathrm{X}_{1}=$ live weight at $5 \mathrm{mths}$

$\mathrm{X}_{2}=$ ultrasonic area of MLD

$\mathrm{X}_{3}=$ width of head

$\mathrm{X}_{\mathrm{i}}=$ width of loin

If the equations are determined with the mean values from all the rams (63 and 61) or only from the slaughtered ones (55 and 51) two estimates are obtained for the dressing weight and the quantity of meat (Table 6).

Table 6. Estimates of dressing weight and quantity of meat obtained with regression equations.

\begin{tabular}{lllllll}
\hline & \multicolumn{3}{c}{ Restricted group } & \multicolumn{3}{c}{ Ad libitum group } \\
& $\mathrm{n}=63$ & $\mathrm{n}=55$ & diff. $\%$ & $\mathrm{n}=61$ & $\mathrm{n}=51$ & diff. $\%$ \\
\hline & & & & & & \\
Live weight $(5$ mths) $\ldots \ldots \ldots \ldots$. & 33.1 & 32.4 & 2.10 & 39.3 & 38.3 & 2.75 \\
Dressing weight estim. .......... & 13.20 & 12.94 & 2.00 & 17.68 & 17.20 & 2.77 \\
Dressing weight real ........... & & 12.93 & & & 17.22 & \\
Meat in leg + shoulder estim. & 2228 & 2191 & 1.67 & 2830 & 2763 & 2.40 \\
Meat in leg + shoulder real & & 2190 & & & 2763 & \\
\hline
\end{tabular}

The difference between these two estimates of dressing weight is proportionally the same as between the live weights. The quantity of meat has not increased as much as the dressing weight when the estimate is based on all the rams. This may be true also in reality because the higher dressing weight of bigger animals is influenced not only by increase of meat but also by higher proportion of fat. In determining the equations it can also be seen that the equations for the ad lib. group are not suitable for the restricted group and vice versa.

From the regression equations an approximate conclusion can also be drawn as to how great an influence the different traits have on the final estimate. The percentual shares of different traits are approximately as follows:

$\begin{array}{cccc}\begin{array}{r}\text { Ad libitum } \\ \text { dressing } \\ \text { weight }\end{array} & \begin{array}{c}\text { quantity } \\ \text { of meat }\end{array} & \begin{array}{c}\text { Restricted group } \\ \text { dressing } \\ \text { weight }\end{array} & \begin{array}{r}\text { quantity } \\ \text { of meat }\end{array} \\ 65 \% & 60 \% & 67 \% & 50 \% \\ 20, & 25 \% & 13 \% & 20 \\ 15 & 15 \% & 20 \% & 30\end{array}$




\section{Selection of rams}

In the selection of rams attention was above all paid to traits of growth and fullness of meat. The rams were first rated according to growth traits (live weight at $\mathbf{5} \mathrm{mths}$ and daily gain). The ordinal numbers after these two ratings were added and two groups were selected from both feeding groups: the 10 best rams and 10 medium rams. After this preselection the rams were rated according to traits for fullness of meat in each of the 4 groups separately: first after each trait, and finally after the sum of the ordinal numbers. The traits for fullness of meat were the following:

- ultrasonic depth of MLD

- circumference of thigh

- mean of widths of loin and chest

- small head (width $\mathrm{x}$ length)

Finally the ordinal numbers of the growth traits were multiplied by four and were added to the ordinals of traits for fullness of meat.In this way the two best and two medium rams were selected from both feeding groups. For each selected ram a reserve ram was selected and some extra rams were furthermore selected. The two best rams of the groups are presented in Tables $7 \mathrm{a}$ and $\mathrm{b}$. The next stage of the experiment in which the majority of the animals will be the progeny of the rams selected now will show how successful this selection has been.

Table 7 a. Two best rams in the restricted group.

\begin{tabular}{|c|c|c|c|c|c|c|}
\hline Ram & $\mathrm{lb} / \mathrm{sl}$ & area & $\begin{array}{l}\text { MLD } \\
\text { depth }\end{array}$ & $\begin{array}{c}\text { surface } \\
\text { fat }\end{array}$ & $\begin{array}{c}\text { Live } \\
\text { weight } \\
(5 \mathrm{mths})\end{array}$ & $\begin{array}{l}\text { Daily } \\
\text { gain }\end{array}$ \\
\hline 27 & $4 / 2$ & 8.6 & 23.5 & 1 & 42.4 & 255 \\
\hline 106 & $3 / 3$ & 10.6 & 26.0 & 0 & 39.8 & 257 \\
\hline \multirow{5}{*}{ Group (63) } & mean $\bar{x}_{1}$ & 9.6 & 24.8 & 0.5 & 41.1 & 256 \\
\hline & mean $\bar{x}_{2}$ & 9.4 & 23.5 & 0.4 & 33.1 & 182 \\
\hline & $\bar{x}_{1}-\bar{x}_{2}$ & +0.2 & +1.3 & +0.1 & +8.0 & +74 \\
\hline & Group s.d. & 0.96 & 1.8 & 0.49 & 4.56 & 31.8 \\
\hline & $\left(\bar{x}_{1}-\bar{x}_{2}\right) /$ s.d. & 0.21 & 0.72 & 0.20 & 1.75 & 2.33 \\
\hline
\end{tabular}

Table $7 \mathrm{~b}$. Two best rams in the ad libitum group

\begin{tabular}{|c|c|c|c|c|c|c|}
\hline Ram & $\mathrm{lb} / \mathrm{sl}$ & area & $\begin{array}{l}\text { MLD } \\
\text { depth }\end{array}$ & $\begin{array}{c}\text { surface } \\
\text { fat }\end{array}$ & $\begin{array}{c}\text { Live } \\
\text { weight } \\
(5 \mathrm{mths})\end{array}$ & $\begin{array}{c}\text { Daily } \\
\text { gain }\end{array}$ \\
\hline 108 & $4 / 3$ & 12.0 & 27.0 & 1 & 47.9 & 363 \\
\hline 66 & $2 / 2$ & 13.2 & 29.0 & 1 & 51.7 & 294 \\
\hline \multirow{5}{*}{ Group (61) } & mean $\bar{x}_{1}$ & 12.6 & 28.0 & 1 & 49.8 & 329 \\
\hline & mean $\bar{x}_{2}$ & 11.6 & 26.6 & 0.9 & 39.3 & 249 \\
\hline & $\bar{x}_{1}-\bar{x}_{2}$ & +1.0 & +1.4 & +0.1 & +10.5 & +80 \\
\hline & Group s.d. & 1.35 & 2.05 & 0.25 & 4.44 & 42.3 \\
\hline & $\left.-\overline{\mathbf{x}}_{2}\right) / \mathrm{s} . \mathrm{d}$ & 0.74 & 0.68 & 0.40 & 2.36 & 1.89 \\
\hline
\end{tabular}

$\mathrm{lb}=$ litter size at birth

$\mathrm{sl}=$ survived in litter 
The selection differential is greatest in live weight and daily gain, as was to be expected (about two standard deviation units). The selection differential in the area of the MLD is very small. It should be noted that the area of the MLD was not a direct object of selection but only a rough estimate of the depth of the muscle. The daily gain of the rams has had a considerable effect on selection. After the analyses it is not, however, advisable to estimate the quantity or fullness of meat. If too much attention is paid to daily gain, animals whose early growth has been low (resulting for example from poor milk yield of their dams) will be given too great a value because they have grown at a faster rate later during the experiment. On the other hand, low live weight in the beginning of the experiment may be the result of a big litter. However, because the high live weight also indicates a high daily gain, the weight of the daily gain in selection is worth examining.

\section{Conclusions}

The ultrasonic measurement of the area of the MLD proved to be useful in estimating the dressing weight and the quantity of meat, because it gave a higher increase than the other measures on live animals on the coefficient of determination based on live weight. However, ultrasonics cannot yet be unreservedly recommended as a practical aid in phenotype testing of rams. Whether the usefulness of ultrasonics covers the costs it necessitates shculd be studied, among other points.

\section{REFERENCES:}

Anon, 1975. Bedømmelse af kødfylde på avlslam. Tidsskr. Faareavl 40, 5: 6-9.

ErkJE, E. 1972. Vaereindeksene. Sau og Geit 25, 2: 72-74.

- 1975. Studies on Sheep Production Records. 8. Estimation of Genetic Change. Acta Agric. Scand. 25: 253-260.

VARO, M. 1968. Lampaiden kasvatuskokeiden tuloksia. Summary: Results of rearing trials with Finnish Sheep. Ann. Agric. Fenn. 7:33-45.

- - \& Hellman, T. 1976. Perusteluja pässien fenotyyppitestaukselle. Abstract: Some arguments on the phenotype testing of rams. J. Scient. Agric. Soc. Finl. 48: 158-169.

VÅBENO, A. 1973. Indirekte mâl for bestemmelse av arealet av den lange ryggmuskelen og lårvekta på lammeslakt. Meld. Norges Landbr. Høgsk. 52: 17.

Ms received October 6, 1976. 


\title{
SELOSTUS
}

\section{Ultraäänikuvauksen käyttö pässien yksilöarvostelussa}

\author{
Tapani Hellman, Matti Ojala ja Mikko Varo \\ Helsingin Yliopiston kotieläinten jalostustieteen laitos, 00710 Helsinki 71
}

Pässien yksilöarvostelukoe, joka aloitettiin vuonna 1975 Pirtin tilalla, on alku kolmivuotiselle tutkimusprojektille. Koejakson aikana pyritään luomaan perusteet jatkuvalle pässien yksilöarvostelulle. Tutkimukseen osallistuvat Maatalouden Tutkimuskeskuksesta Kotieläinjalostuslaitos ja Kotieläinhoidon Tutkimuslaitos, Lampaanjalostusyhdistys ja Helsingin Yliopiston kotieläinten jalostustieteen laitos. Tässä artikkelissa on tarkasteltu lähinnä ultraäänikuvauksen käyttöä, mikä on yliopiston tehtävänä projektissa.

Kokeen perusaineisto, 130 pässiä, hankittiin tarkkailukatraista eri puolilta Suomea. Pässit olivat kahdella eri ruokintatasolla: vapaasti heinää ja väkirehua, vapaasti heinää ja rajoitetusti väkirehua. Pässit kasvatettiin 5 kk:n ikään ja niiden painot ja lisäkasvut olivat seuraavat:

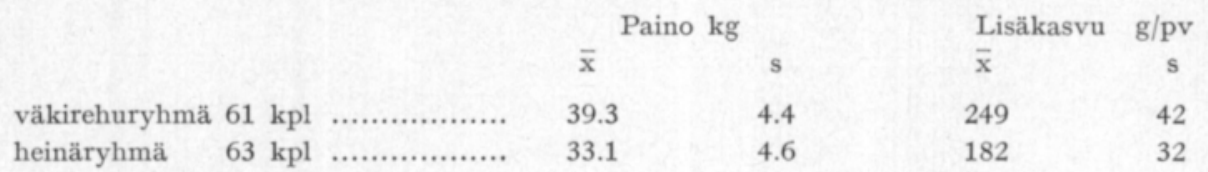

Ultraäänikuvaus suoritettiin keskimäärin 163 päivän iässä ja pitkän selkälihaksen pintaalat olivat väkirehuryhmässä $11.6 \mathrm{~cm}^{2}(\mathrm{~s}=1.35)$ ja heinäryhmässä $9.4 \mathrm{~cm}^{2}(\mathrm{~s}=0.96)$. Ultraäänikuvista määritettiin myös pitkän selkälihaksen paksuus ja pintarasva.

Eri ominaisuuksien käyttömahdollisuuksia pässien arvostelussa tutkittiin laskemalla askeltavalla regressioanalyysillä lihamäärän ja lihakkuuden selitysasteita. Ultraäänikuvasta mitatun pitkän selkälihaksen pinta-alan todettiin eniten lisäävän elopainon antamia selitysasteita. Vaikka lisäys oli tilastollisesti merkitsevä, se oli melko pieni. Yleensä lihakkuuden selitysasteet jäivät melko pieniksi $\left(R^{2}<40\right)$ verrattuna lihamäärän melko täydelliseen selittymiseen $(80$ $\left.<\mathrm{R}^{2}<90\right)$.

Pässeistä valittiin kaksi parasta ja kaksi keskimmäistä kummastakin ruokintaryhmästä. Valinnassa oli suurin paino painolla ja lisäkasvulla $(4 / 5)$ ja pienempi paino selkälihaksen ultraaannimitoilla ja rungon mitoilla (1/5). Valitut pässit tulevat olemaan isinä seuraavalle yksilöarvosteluryhmälle, josta saadaan siis myös jälkeläisarvostelu nyt valituille pässeille. 